\title{
Strike Deadlines: Of What Use Are They?
}

\author{
Onabanjo Idowu
}

\section{Chidi Odogwu Christopher}

\begin{abstract}
This article is intended to be an advocacy paper against setting of strike deadlines before embarking on strikes. In public sector for example, unions have realized that the only language government understands is strike, and when union gives deadlines, government barely takes action to call union to the negotiation table. Rather it embarks on campaign of calumny, which is a way of beating about the bush. This paper illustrates that despite strike deadlines, strikes still occur. This shows that some strikes are unavoidable. This paper gives reasons making some strikes unavoidable despite the huge cost of strikes and the warning given through the deadlines.
\end{abstract}

Key words: Strike, deadlines, use

\section{INTRODUCTION}

Strike deadlines are generally perceived as an opportunity to do whatever is necessary to avoid strikes, since strikes are considered to be very costly both to labour and management. However, some union leaders consider strikes as a proving ground to show that unions not only bark but are capable of biting. It is used to support the saying that all work and no play makes jack a dull boy. Strikes are also considered as a way for labour, for once to call the shot rather than management to always issue instructions which labour is bound to obey. It is an occasion for union members to show solidarity. Surprisingly, management may incite strike to present an occasion to sell its unsold goods stockpiled in the warehouse. In the event that a strike is perceived as an opportunity to have one's way, a strike deadline serves no useful purpose in averting it.

\section{What is a strike?}

A strike has been defined as "a temporary stoppage of work by a group of employees in order to express a grievance or enforce a demand." This definition was expatiated upon, to the effect that the temporary nature of strikes suggests that at its conclusion the strikers should return to the same jobs with the same employer, who himself normally views a stoppage in the same terms.

A strike is a collective act, undertaken by a group of employees. The fact that the group involved in the act is of employees is also crucial. Refusal by students to attend lectures is called a strike only by analogy. A strike is almost always a calculative act, designed 'to express a grievance or enforce a demand (Griffin, 1939:20-2) Hyman (1971: 17)

\section{Varieties of Strikes}

Broadly speaking, there are general strikes, political strikes, and strikes limited to a company or an industry. A general strike is that undertaken by nearly all sectors of the economy. Unlike strikes limited to a company or industry it is directed to the government or the state to express grievance or enforce a demand. A political strike has been referred to as illegitimate use of industrial muscle aimed at destroying a government by precipitating a revolution. 
In strikes limited to a company or an industry, we could distinguish an avoidable strike, an unavoidable strike, official strike, an unofficial strike, a constitutional strike and an unconstitutional strike. An avoidable strike is that given the circumstances of the issue at stake could have been avoided within the time- frame of the strike deadline.

Here the true positions of the parties overlap, so that an omniscient observer could prescribe a solution acceptable to both. An unavoidable strike is that in which the final positions of the parties fail to overlap, so that each prefers a shutdown to further concessions.

An unconstitutional strike is initiated in contravention of a status-quo clause in most grievance/dispute procedures stating that industrial action, by either party, should not be undertaken until all the stages of the procedure have been exhausted. An unconstitutional strike breaches the jointly agreed and established procedure for resolving differences between management and employees; acceptance of the use of unconstitutional strike may be tantamount to repudiation of the regulatory framework itself. Arising from the above definitions, it could be safely stated that a constitutional strike follows constitutionally laid down procedure for embarking on a strike, while an official strike is that which receives the blessing of union leaders.

A strike is part of a generic concept referred to as industrial conflict. Industrial conflict has been defined by various authors and one that seems to be popular is that proffered by Kornhauser, Dubin and Ross (1954). They describe Industrial conflict as "total range of behavior and attitudes that express opposition and divergent orientations between individual owners and managers on the one hand, and working people and their organizations on the other" (p.13).

Hyman (1971:53) cited Clark Kerr (1964) who described industrial conflict to be of various forms which include peaceful bargaining and grievance handling, boycotts, political action, restriction of output, sabotage, absenteeism, personnel turnover, insubordination and physical attack, overtime bans and strikes. Several of these forms, such as sabotage, restriction of output, absenteeism and turnover may take place on an individual as well as on an organized basis and constitute alternatives to collective action. Hyman also pointed out that the various forms of conflict are alternatives and that in an industrial situation in which workers experience sufficiently acute deprivations, unrest will be expressed in some form. The circumstances of the case will however influence what form this expression of conflict takes. Thus, in any situation the different varieties of industrial conflict may represent alternatives. Hyman (1971:55) recalled the observation made in Sayles (1958:8) to the effect that there was evidence of worker discontent, but often it was not found in terms of specific demands or grievances - he then suggested that attempts to suppress specific manifestations of conflict, without removing the underlying causes of unrest may merely divert the conflict into other forms.

\section{Strike deadlines}

A strike deadline is an outcome of negotiation indicating that an impasse has been hit and a period of grace is given to management to reconsider her stand to improve the status quo, failure of which would leave labour with no other option than a strike. Succintly put, it is the date at which a collective bargaining contract expires and a strike can start if a settlement is not reached. An impasse is the point in negotiations where no compromise appears achievable and a strike or lockout is imminent. Reynolds (1949:184) pointed out that it has been said that: 
"war is a continuation of diplomacy by other methods." Similarly, A strike is a continuation: of bargaining by other methods and it is an intrinsic part of the bargaining process.

Ross (1988) pursued this argument further by averring that deadlines can motivate progress in negotiation and without a deadline, negotiators may be tempted to use stalling strategies with the goal of convincing their counterpart to make more concessions. As Pfeffer (1992) observed "Deadlines are an excellent way of getting things accomplished. They convey a sense of urgency and importance and provide a useful countermeasure to the strategy of interminable delay."

\section{The Right to Strike}

Johnston (1981: 136) cited Crofter Harris Tweed v. Veitch in which Lord Wright pronounced in 1942 that "the right of workmen to strike is an essential element in the principle of collective bargaining" Fleming (1965:203) in Johnston (1981: 136) an American authority writes about strikes as follows:

"But a strike is more than a test of strength over a particular issue. It is also a release from the humdrum existence of everyday industrial life, a proving ground for union leaders, a moment of excitement, glory and perhaps disillusionment in a battle against an opponent who usually holds the upper hand, a sharing of hardship which may weld the union together, and a highlevel poker game at which plays and counter plays are expressed."

The possibility of a strike, which both sides are usually anxious to avoid, leads them to make concessions and seek agreement. If negotiations break down and a strike occurs, this exerts continuing pressure on both sides to reach a settlement....Without the possibility of a strike in the background, there is no reason why an employer should make any concession whatever to a union. Yet disputes between unions and management would still have to be settled somehow. The only possible way of settling them with strikes eliminated is through compulsory arbitration by a government agency (Reynolds, 1949). Reynolds pointed out that while the "right to strike is often confused with the right of a worker to quit his job, the two things are quite different. A worker quits his job when he wishes permanently to sever his connection with the employer. It is possible for this concerted activity to be unlawful even though each worker as an individual has the right to stop work whenever he wants to."

\section{Management Consideration before the Expiration of Strike Deadline}

Once a strike deadline has been hit, management is no longer at ease, it works round the clock either to stall the strike or call the union's bluff. Management considers its prerogatives as inviolable, hence management cannot but take a strike if any union demand impinges on such prerogatives. Also, if the union's minimum wage demand is above management's maximum it is likely that management will call the union's bluff. Many companies see trade unions as voluntary organizations hence any agreement forcing workers to be members of a union is not honoured as a result of management policy. In addition, consideration is given to short and long term implications of settling without a strike. Management also considers the cost of strike which involves possible loss of profits, customers, suppliers. It also involves deterioration of machinery resulting from being left idle and also possible damage to company property by strikers. Public visibility of strikes particularly in a case of essential services is also of grave concern. (Otobo, 2000)

Otobo (2000:276) reported various factors considered before a union decides to go on strike, bearing in mind the commonplace belief of not threatening strike unless you are ready for it. 


\section{Union Consideration}

What effect will calling a strike or, conversely, agreeing on a contract without a strike, have on the union's policies, aims and goal? These policies and goals are held to be of the greatest importance and, if necessary, are defended at the cost of a strike. Basic policies are set forth in the union's constitution and in convention resolutions.

What are the long-term and short-term implications of settling without a strike? This is closely related to the first consideration mentioned, but in addition, involves the effect of a settlement upon the internal or external strength of the union, upon the wants and attitudes of its members, and upon its reputation in the community and with other unions.

What is the strength of the union and its ability to shut down the company's operations? This includes whether all or most of the members of the union can be persuaded to stay off the job, whether non-members can be encouraged to do the same, and whether other unions will cooperate with striking union.

To what extent will the striking members be able to withstand the loss of salaries? Will they be able to secure work elsewhere? To what extent will the union itself be able to provide strike benefits to its members? In addition to the financial aspect, union leaders try to evaluate the amount of moral support for the strike they can expect from both strikers and their families. Do they attach importance to the issues at stake?

To what extent will public opinion be sympathetic - or at least, not antagonistic- to the purposes of the strike? What role will government be expected to take in the event of a strike? In the case of major work stoppages and those immediately and directly affecting the community welfare (such as hospital strikes), will there be governmental interference in the form of fact-finding boards, attempts At mediation or conciliation and the like? Which government laws or legislation restrict the conduct of strikes?

\section{Settlement of Disputes Without Strikes}

Just as police stations are set up in the larger society to arrest aberrant behaviours so the state has set up parliamentary bodies to institutionalize conflict among which is the strike. The one specifically used to arrest strike is compulsory arbitration. Much controversy surrounds the use of compulsory arbitration. When used, the state justifies its use by what they refer to as 'threat to public interest' in the sense that development plans could be disrupted and or the general public could be denied of the utilities classified as essential services.

\section{Fanciful Reasons Making strikes Desirable In the Face of Deadlines}

Despite strike deadlines different fanciful reasons have been adduced for the desirability of strikes. An employer may regard a strike as a good way of breaking a weak union and freeing himself from the necessity of collective bargaining. On the other side a radical union leader may regard a strike as desirable to build up revolutionary fervor and hatred of "the capitalists", even when there is no chance that strike will win any immediate benefits. Second, a strike may occur because of inability of the parties to compromise their positions. Third, even where compromise is possible, one side may be willing to compromise because it has a low opinion of the others strength and thinks it can win its point easily and quickly.

Another reason as contained in (Hicks 1932:146) is that "weapons grow rusty and a union which never strikes may lose the ability to organize a formidable strike, so that its threats become less effective." Also Hyman (1971:35) quoting (Turner et al., 1967:331) "the frequency 
with which managements themselves lay men off... makes it seem nothing abnormal for workers to withhold their labour'. Hyman (1971:36) continued in that argument and inferred that a stoppage, then, may not be unwelcome in all situations. It has been argued that the Post Office made a profit out of the 1971 dispute: the strike closed down the letter and parcel service, which had been running at a loss, but there was a large increase in use of the profitable telephone service (Foot, 1971:15). The cynic might suspect that in some circumstances a strike could even be provoked - when an employer is faced by production difficulties or dwindling order books.

Reynolds (1949:185), believed that in order to discover the "causes" of strikes, despite deadlines it is necessary to find out the circumstances in which agreements between the parties become impossible. The following are some of the circumstances according to him

\section{One of the Parties Wants a Strike}

When an employer feels a strike would occasion a break from a weak union thus freeing himself from the necessity of collective bargaining. On the other hand, a radical union leader may consider a strike desirable to build workers' fervor/solidarity.

\section{Inability of Both Sides to Compromise}

A union may insist on a wage higher than the company can pay. A union leader may realize that their demands are impossible but to retreat would jeopardize their own positions and perhaps split the union.

\section{Negotiators are Not Free Agents}

Negotiators are not free agents: they derive authority and ratification from their principals hence there is a limit to how far they can go or what decisions they can make at the bargaining table. Another factor is membership pressure which may force union negotiators to maintain a position which they know the company may not accept.

\section{Misconception of The Intention of the Opposing Sides}

This is exemplified by calling a bluff which turns ou not to be a bluff after all. The employer can cause a strike by doing nothing; the union then has to take the positive step of calling out the workers. This would force the employer to the negotiation table -A strike is the continuation of bargaining by other methods. It is a route to agreement. Reynolds (1949: 185)

Herman et al. (1992:) believed that at the back of negotiators' minds are the following questions and answers to them could precipitate strike. "could the union shut down the plant completely by a strike, and if so for how long? How much would this cost the company and how much would it cost the union? Which is in the better position to take such a loss, and which would probably crack first?

Salamon (1992:77) cited a suggestion made by Blackburn (1967) to the effect that a trade union must be prepared to be militant - use industrial action. This is in line with an affirmation that trade unionism is a fighting movement and that movement implies a common end or at least a community of purpose which is real and influences men's thoughts and actions. A trade union must not get into such peaceable habit. It must have teeth to bite and be ready to fight.

\section{CONCLUSION}

Considering the high cost of strikes to both management and labour, one would think that a strike deadline should be an opportunity to avert a strike. However, looking at the situation from different perspectives, some strikes are considered desirable and in such a situation, no 
amount of strike deadlines can avert such strikes. A panorama of strikes in Nigeria from 1945 General Strike up to the recent 2013 General Strike occasioned by hike in fuel price reveals that despite strike deadlines given, strikes still occur. Even with ban on strikes or no work no pay threats, this was not sufficient to avert strikes. In the public sector, when collective bargaining is adopted, government does not show commitment. For instance in 2017 Academic Staff Union of Universities (ASUU) strike, the Minister of Education, Adamu Adamu said that late last year ASUU gave one week notice of strike and government and Asuu were able to work out an agreement. However, government has not fulfilled its part of the bargain. Hence the minister admitted that government failed ASUU. Guardian (2017, August 17). More importantly, a situation where either the management or the union desires a strike, a strike deadline is of no use! There have occurred series of strikes despite the deadlines given. To mention just a few, is the Birmingham bin strike reported on 13 September 2017; London tube strike reported on29 September 2017 which was reported would hit commuters and football fans next week; Rail strike set to disrupt services across England was reported on4 October 2017 all reported in Industrial action UK-news

\section{References}

Blackburn, R. (1967) 'The Unequal Society’ in Blackburn and Cockburn A (eds.) The Incompatibles: Trade Union Militancy and the Consensus, Harmondsworth: Penguin

Foot, P. (1971) The Portal Workers and the Tory Offensive, London: Socialist Worker

Griffin, J.I. (1939) Strikes: A Study in Quantitative Economics, New York: Columbia University Press

Herman, E.E., Schwarz, J.L. and Kuhn Alfred (1992) Collective Bargaining and Labor Relations, New Jersey:

Prentice Hall, Inc.

Hyman, R. (1971) Strikes, UK: Fontana

Johnston, T.L. (1981) An Introduction to Industrial Relations, Great Britain: Macdonald and Evans Ltd.

Kerr, C. (1964) Labour and Management in Industrial Society, New York: Doubleday

Kornhauser, A., Dublin, R., \& Ross, A. (eds.), (1954) Industrial Conflict, New York: McGraw-Hill

Otobo, D (2000) Industrial Relations: Theory and Controversies, Lagos: Malthouse Press Ltd

Pfeffer, J. (1992) Managing with Power: Politics and Influence in Organisations, Boston: Harvard Business School Press. https://www.guardian.com

Reynolds, L.. G. (1949) Labor Economics and Labor Relations, New York: Prentice-Hall, Inc.

Ross, W. H. (1988) Situational Factors and Alternative Dispute Resolution Journal of Applied Behaviour Science, $24,251-262$

Salamon, M. (1992) Industrial Relations, UK: Prentice Hall International Ltd.

Sayles, L. R. (1958) The Behaviour of Industrial Work Groups, New York: Wiley 